\title{
USING HYBRID POWER FILTER TO MITIGATE CURRENTS AND VOLTAGES HARMONICS IN THREE PHASE SYSTEM
}

\author{
Y. DJEGHADER*, L.ZELLOUMA** \\ *Department of Electrical Engineering, University of Souk Ahras ALGERIA; Email: djeghaderyacine@yahoo.fr \\ ${ }^{* *}$ Department of Electrical Engineering, University of El-Oued ALGERIA.
}

\begin{abstract}
This paper describes different power quality problems in distribution systems and their solutions with power electronics based equipment. A hybrid power filter in combined system of shunt passive and series active power filter has been designed and simulate with Matlab/Simulink. This filter is a three level PWM voltage source inverter and we use a fuzzy logic controller algorithm to control the harmonic voltages. The viability of the proposed algorithm is validated in this work. This hybrid power filter is able to compensate the reactive power (showed that source voltage is sinusoidal and in phase with source current), and harmonics (voltage \& current) for three phase of the non linear load current proposed with RL and RC load. The proposed solution has achieved an improvement of power quality in distribution system specifically the reduction of currents and voltages harmonics, we see that through the values of THDI and THDV that are still below the IEC (61000) standard after filtering.
\end{abstract}

Keywords: Active Power Filter, Hybrid Filter, Passive Filter, Power quality, Harmonics; THD; fuzzy controller

\section{INTRODUCTION}

The increased severity of harmonic pollution in power networks with the development of power semiconductors and power-electronics application techniques has attracted the attention to develop dynamic and adjustable solutions to the power quality problems. These power harmonics are called electrical pollution which will degrade the quality of the power supply. As a result, filtering process for these harmonics is needed in order to improve the quality of the power supply.

Therefore, these harmonics must be mitigating. In order to achieve this, series or parallel configurations or combinations of active and passive filters have been proposed depending on the application type [1], [2]. Traditionally, a passive $L C$ power filter is used to eliminate current harmonics when it is connected in parallel with the load [3]. This compensation equipment has some drawbacks mainly related to the appearance of series or parallel resonances because of which the passive filter cannot provide a complete solution. Since the beginning of the 1980s, active power filters (APFs) have become one of the most habitual compensation methods [4]. A usual APF consists of a three-phase pulse width modulation (PWM) voltage source inverter. The APF can be connected either in parallel or in series with the load. The first one is especially appropriate for the mitigation of harmonics of the loads called harmonic current source. In contrast, the series configuration is suitable for the compensation of loads called harmonic voltage source. However, the costs of shunt active filters are relatively high for large-scale system and are difficult to use in highvoltage grids. In addition, their compensating performance is better in the harmonic current source load type than in the harmonic voltage source load type [7], [8].

\section{POWER QUALITIES AND THEIR SOLUTION}

Power Quality (PQ) related issues are of most concern nowadays. The widespread use of electronic equipment, such as information technology equipment, power electronics such as adjustable speed drives (ASD), programmable logic controllers (PLC), energy-efficient lighting, led to a complete change of electric loads nature [8]. These loads are simultaneously the major causers and the major victims of power quality problems. Due to their non-linearity, all these loads cause disturbances in the voltage waveform Along with technology advance, the organization of the worldwide economy has evolved towards globalization and the profit margins of many activities tend to decrease. The increased sensitivity of the vast majority of processes (industrial, services and even residential) to $\mathrm{PQ}$ problems turns the availability of electric power with quality a crucial factor for competitiveness in every activity sector. There are two approaches to the mitigation of power quality problems. The first approach is called load conditioning, which ensures that the equipment is less sensitive to power disturbances, allowing the operation even under significant voltage distortion. The other solution is to install line conditioning systems that suppress or counteracts the power system disturbances. A flexible and versatile solution to voltage quality problems is offered by active power filters. Currently they are based on PWM converters and connect to low and medium voltage distribution system in shunt or in series. Series active power filters must operate in conjunction with shunt passive filters in order to compensate load current harmonics. Shunt active power filters operate as a controllable current source and series active power filters operates as a controllable voltage source [6], [9]. Both schemes are implemented preferable with voltage source

PWM inverters, with a dc bus having a reactive element such as a capacitor. Active power filters can perform one 
or more of the functions required to compensate power systems and improving power quality [7], [11].

\section{SERIES APF TOPOLOGY DESCRIPTION AND MODELING}

\subsection{Description of the APF Topology}

Fig. 1 shows the topology of the combined SAPF and shunt passive filter (PF), acting as zero impedance for the fundamental frequency and as high resistor for the harmonics frequencies. The APF, which is supplied by a low power PWM inverter, is connected in series with the main supply and the non-linear load through the current transformer. The passive filter connected in parallel to the load is used to damp the $5^{\text {th }}$ and the $7^{\text {th }}$ harmonic of $V_{l}$ because of their high amplitudes

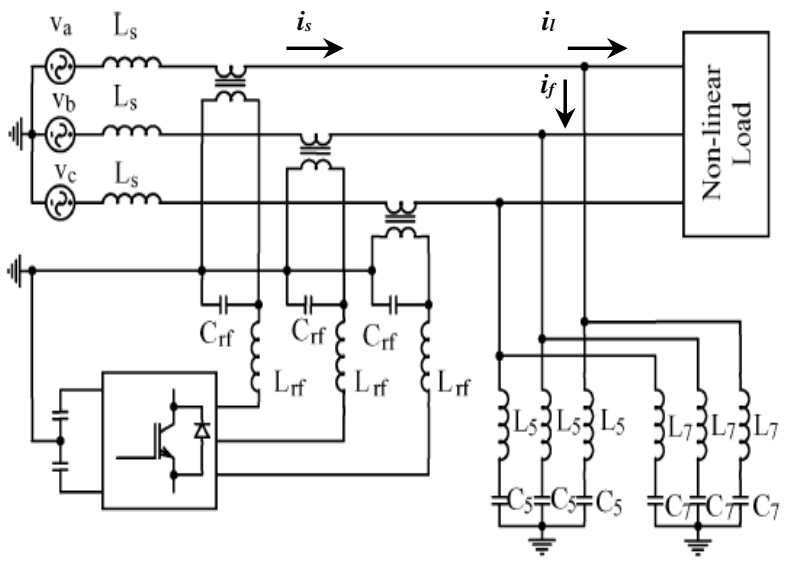

Fig. 1 General Configuration of a combined filter

The series APF acts as a voltage source and inject a compensating voltage in order to obtain a sinusoidal load voltage. The developments in digital electronics, communications and in process control system have made the loads very sensitive, requiring ideal sinusoidal supply voltage for their operation

\subsection{Modeling}

Fig.2. shows the per-phase equivalent scheme of the studied topology

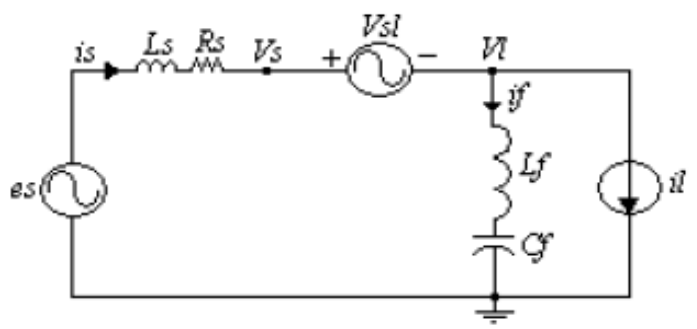

Fig. 2 Per-phase equivalent scheme. $e_{s}, i_{s}, L_{s}, R_{s}$ : Source voltage, source current, source inductance, and source resistance,

$V_{s}$ : Line voltage,

$V_{l}, i_{l}:$ Load voltage and load current,

$V_{s l}$ : Controllable voltage source representing the series active power filter,

$i_{f}, C_{f}, L_{f}$ : Shunt passive filter current, passive filter capacitance, and passive filter inductance.

This equivalent scheme is modeled by (1) and (2):

$$
\begin{aligned}
& V_{s l}=V_{s}-V_{l} \\
& i_{s}=i_{f}+i_{l}
\end{aligned}
$$

Where,

$$
V_{s}=e_{s^{-}}\left(R_{s} \cdot i_{s}\right)-\left(L_{s} d t / d i_{s}\right)
$$

The voltage error is given by:

$$
\begin{aligned}
& \Delta V_{s l}=V_{\text {slref }}-V_{s l} \\
& V_{\text {slref }}: \text { is expressed by: } \\
& V_{\text {slref }}=V_{s h}-V_{l h} \\
& V_{s h}=k . i_{s h}
\end{aligned}
$$

$V_{s h}, V_{l h}, i_{s h}$ : represent, respectively, the harmonic components present in $V_{s}, V_{l}$, and $i_{s}$.

$k$ : is a current sensor gain.

\subsection{APF Voltage references determination}

The harmonic component $V_{s l h}$ of $V_{s l}$ is defined by:

$$
V_{s l h}=V_{s l}-V_{s l f}
$$

First, we extract the $p-q$ components of $V_{s l}$ :

$$
\left[\begin{array}{l}
V_{s l p} \\
V_{s l q}
\end{array}\right]=C_{p q} C_{32}\left[\begin{array}{l}
V_{l a} \\
V_{l b} \\
V_{l c}
\end{array}\right]
$$

$C_{p q}, C_{32}$ representing the Park matrix and Concordia matrix given respectively by:

$$
\begin{aligned}
& C_{p q}=\left[\begin{array}{cc}
\sin (\omega t) & -\cos (\omega t) \\
-\cos (\omega t) & -\sin (\omega t)
\end{array}\right] \\
& C_{32}=\sqrt{2 / 3}\left[\begin{array}{ccc}
1 & -1 / 2 & -1 / 2 \\
0 & \sqrt{3} / 2 & -\sqrt{3} / 2
\end{array}\right]
\end{aligned}
$$

Where: 
Next, decomposition of $V_{s l p}$ and $V_{s l q}$ into continuous components $\overline{\mathrm{V}}_{\text {slp }}, \overline{\mathrm{V}}_{\text {slq }}$ and alternative components $\widetilde{\mathrm{V}}_{\text {slp }}, \widetilde{\mathrm{V}}_{\text {slq }}$

$$
\begin{aligned}
& V_{s l p}=\overline{\mathrm{V}}_{\mathrm{slp}}+\widetilde{\mathrm{V}}_{\mathrm{slp}} \\
& V_{s l q}=\overline{\mathrm{V}}_{\mathrm{slq}}+\widetilde{\mathrm{V}}_{\mathrm{slq}}
\end{aligned}
$$

$\overline{\mathrm{V}}_{\text {slp }}, \overline{\mathrm{V}}_{\text {slq }}$ are obtained via a second order low-pass filter.

Then, the obtained three-phase fundamental components are presented below:

$$
\left[\begin{array}{l}
V_{\text {slfa }} \\
V_{\text {slfb }} \\
V_{\text {slfc }}
\end{array}\right]=C_{32} C_{p q}^{-1}=\left[\begin{array}{l}
\overline{\mathrm{V}}_{\text {slp }} \\
\overline{\mathrm{V}}_{\text {slq }}
\end{array}\right]
$$

Finally, this algorithm can be represented as shown in the block diagram of Fig.3.

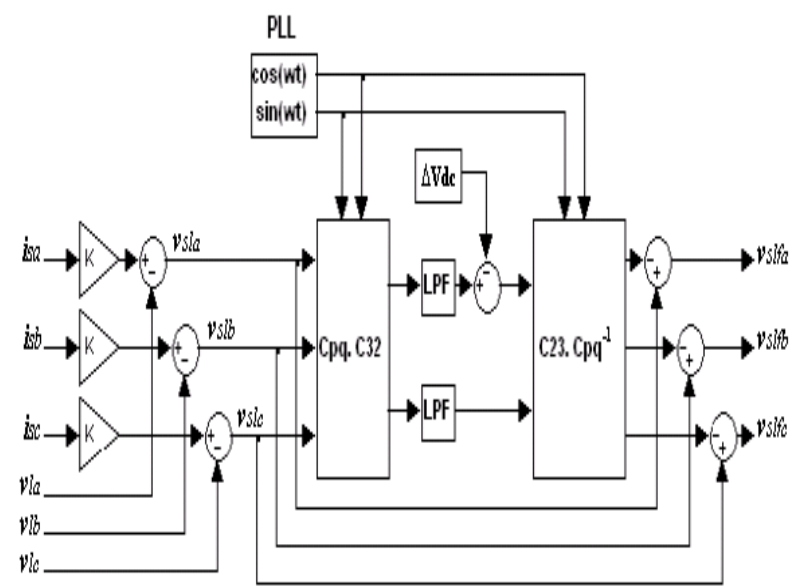

Fig. 3 Block diagram of voltages references determination

\subsection{Inverter control using PWM}

The control method is aimed to control PWM inverter to produce the desired compensation voltage, in the output of series APF. This method is achieved by implementing a fuzzy logic controller [5-10] which starts from the difference between the injected voltage $\left(V_{i n j}\right)$ and the calculated reference voltage $\left(V_{s l f}\right)$ that determines the reference voltage of the inverter (modulating wave). This reference voltage is compared with two carrying triangular identical waves shifted one from other by a half period of chopping producing the control signal to control the onoff of the IGBT. The general block diagram of voltage control is shown in Fig.4.

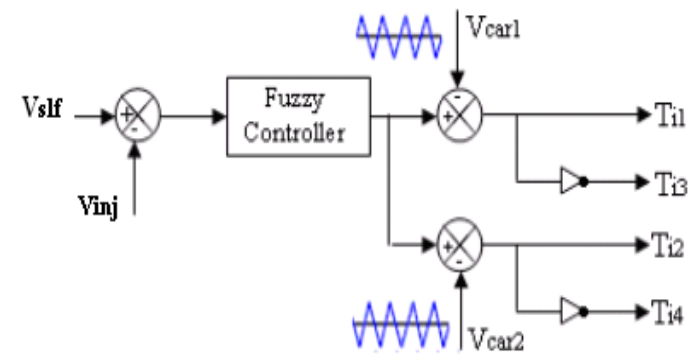

Fig. 4 PWM synoptic block diagram of voltage control

The control of inverter arm constituting the series active filter is summarized in the two following steps.

- Determination of the intermediate signals $\mathrm{V}_{\mathrm{i} 1}$ and $\mathrm{V}_{\mathrm{i} 2}$.

Iferror $\geq$ carrying $1 \Rightarrow V_{i 1}=1$

$\mathrm{I}_{\mathrm{f}}$ error $<$ carrying $1=>V_{\mathrm{i} 1}=0$

If error $\geq$ carrying $2 \Rightarrow>V_{\mathrm{i} 2}=0$

If error < carrying $2 \Rightarrow>V_{i 2}=-1$

Determination of control signals of the switches $\mathrm{T}_{\mathrm{ij}}(\mathrm{j}=1,2,3,4)$.

$$
\begin{aligned}
& \text { If }\left(\mathrm{V}_{\mathrm{i} 1}+\mathrm{V}_{\mathrm{i} 2}\right)=1 \Rightarrow \mathrm{T}_{\mathrm{i} 1}=1, \mathrm{~T}_{\mathrm{i} 2}=1, \mathrm{~T}_{\mathrm{i} 3}=0, \mathrm{~T}_{\mathrm{i} 4}=0 \\
& \text { If }\left(\mathrm{V}_{\mathrm{i} 1}+\mathrm{V}_{\mathrm{i} 2}\right)=0 \Rightarrow \mathrm{T}_{\mathrm{i} 1}=0, \mathrm{~T}_{\mathrm{i} 2}=1, \mathrm{~T}_{\mathrm{i} 3}=1, \mathrm{~T}_{\mathrm{i} 4}=0 \\
& \text { If }\left(\mathrm{V}_{\mathrm{i} 1}+\mathrm{V}_{\mathrm{i} 2}\right)=-1 \Rightarrow \mathrm{T}_{\mathrm{i} 1}=0, \mathrm{~T}_{\mathrm{i} 2}=0, \mathrm{~T}_{\mathrm{i} 3}=1, \mathrm{~T}_{\mathrm{i} 4}=1
\end{aligned}
$$

\subsection{Fuzzy Control Application}

Fuzzy logic serves to represent uncertain and imprecise knowledge of the system, whereas fuzzy control allows taking a decision even if we can't estimate inputs/outputs only from uncertain predicates. Fig. 5, shows the synoptic scheme of fuzzy controller, which possesses two inputs (the error $(e)$,

$\left(e=V_{s l f}-V_{i n j}\right)$ and its derivative $\left.(d e)\right)$ and one output (the command $\left(c_{d e}\right)$ ). [5]

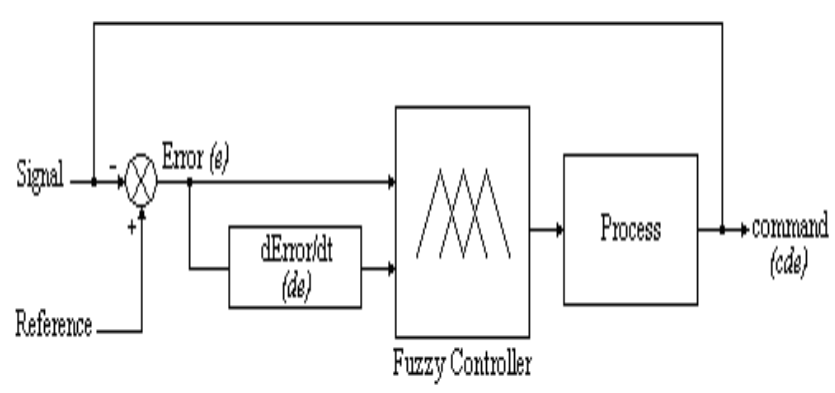

Fig. 5 Fuzzy controller synoptic diagram 


\section{SIMULATION RESULTS}

The simulation is carried out using a program working in MATLAB/ Simulink environment. For non linear load we use a three phase diode rectifier with RL and RC load

Table 1 System Parameters

\begin{tabular}{|c|c|c|}
\hline \multirow{2}{*}{ Source } & $\mathrm{e}_{\mathrm{s}}$ & $230 \mathrm{~V}$ \\
\cline { 2 - 3 } & $\mathrm{L}_{\mathrm{s}}$ & $5,5 \mathrm{mH}$ \\
\cline { 2 - 3 } & $\mathrm{R}_{\mathrm{s}}$ & $3,6 \Omega$ \\
\hline \multirow{2}{*}{ Load } & $\mathrm{R}$ & $25 \Omega$ \\
\cline { 2 - 3 } & $\mathrm{L}$ & $55 \mathrm{mH}$ \\
\hline & $\mathrm{C}$ & $2200 \mu \mathrm{F}$ \\
\hline \multirow{2}{*}{ Passive filter } & $\mathrm{L}_{\mathrm{f5}} ; \mathrm{C}_{\mathrm{f}}$ & $13,5 \mathrm{mH} ; 30 \mu \mathrm{F}$ \\
\cline { 2 - 3 } & $\mathrm{L}_{\mathrm{f} 7} ; \mathrm{C}_{\mathrm{f} 7}$ & $6,75 \mathrm{mH} ; 50 \mu \mathrm{F}$ \\
\hline Ripple filter & $\mathrm{L}_{\mathrm{fr}} ; \mathrm{C}_{\mathrm{fr}}$ & $13,5 \mathrm{mH} ; 50 \mu \mathrm{F}$ \\
\hline Turns Ratio of Coupling Transformer & $1: 1$ \\
\hline \multicolumn{2}{|c|}{ Switching Frequency } & $20 \mathrm{KHz}$ \\
\hline
\end{tabular}

\subsection{Simulation Results before Filtering}

$\underline{\text { Simulation Results with RL Load }}$
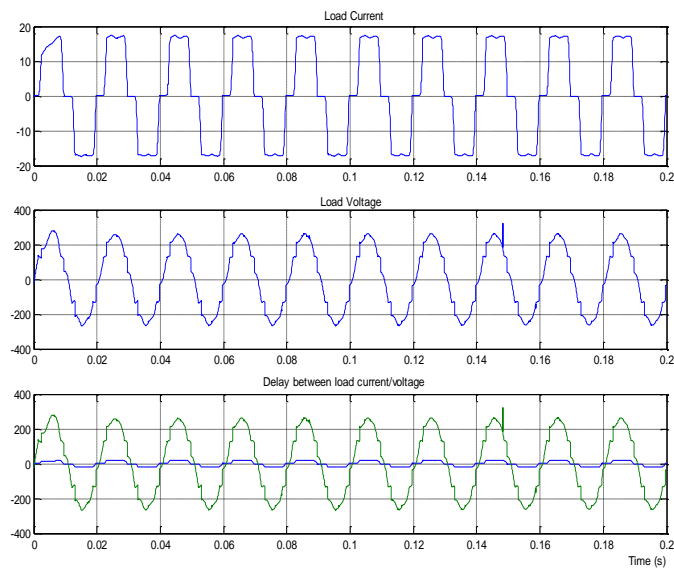

Fig. 6 Waveforms of load (current, voltage), and their delay for RL

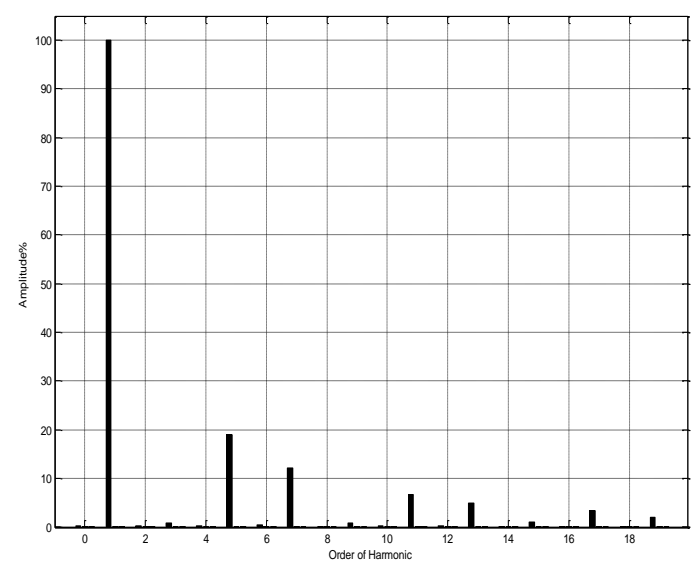

Fig. 7 Harmonic Spectrum of current

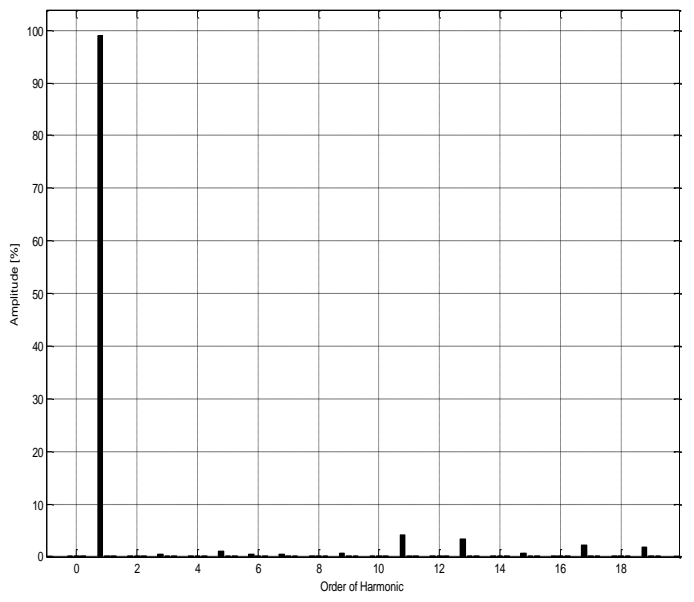

Fig. 8 Harmonic Spectrum of voltage

$\underline{\text { Simulation Results with RC Load }}$
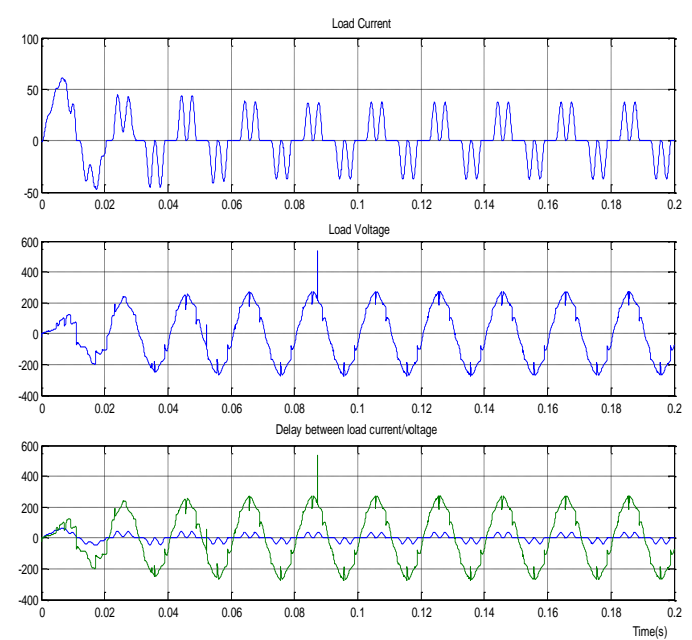

Fig. 9 Waveforms of load (current, voltage), and their delay for $\mathrm{RC}$

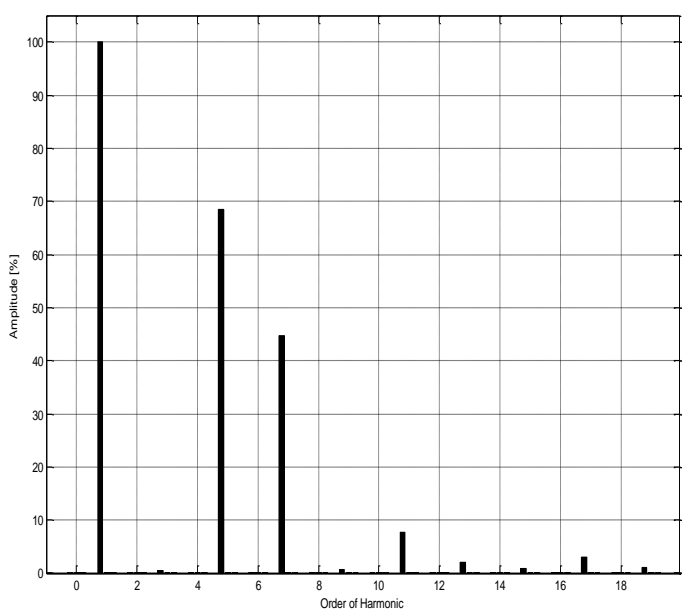

Fig. 10 Harmonic Spectrum of current 


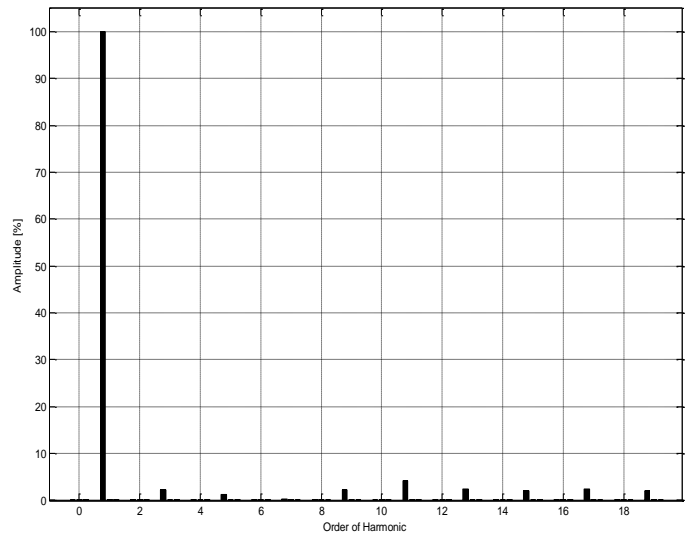

Fig. 11 Harmonic Spectrum of current voltage

\subsection{Simulation Results after Filtering}

$\underline{\text { Simulation Results with RL Load }}$
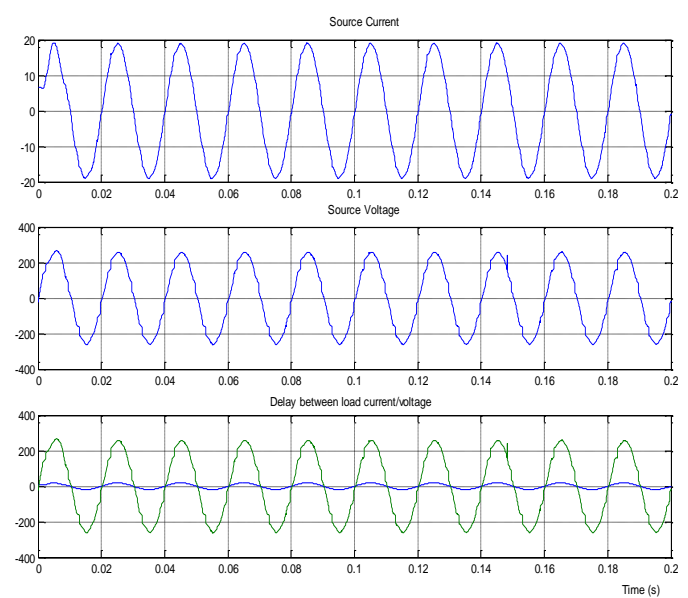

Fig. 12 Waveforms of sources (current, voltage), and their delay HP
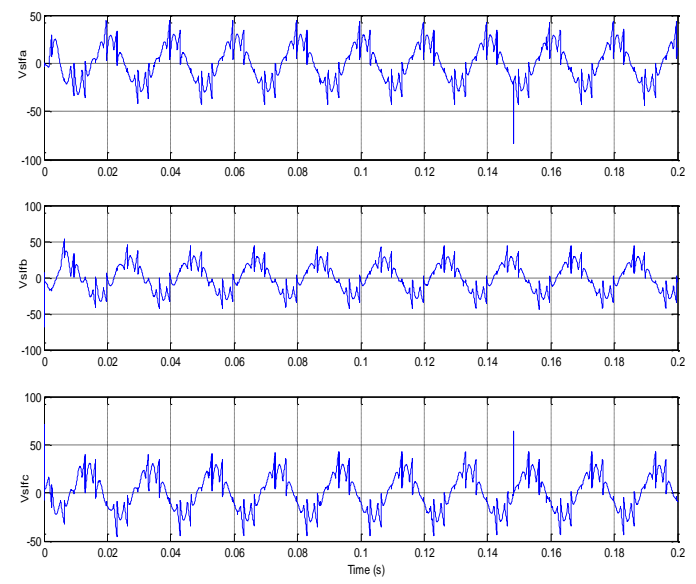

Fig. 13 Voltages references of HF for RL load

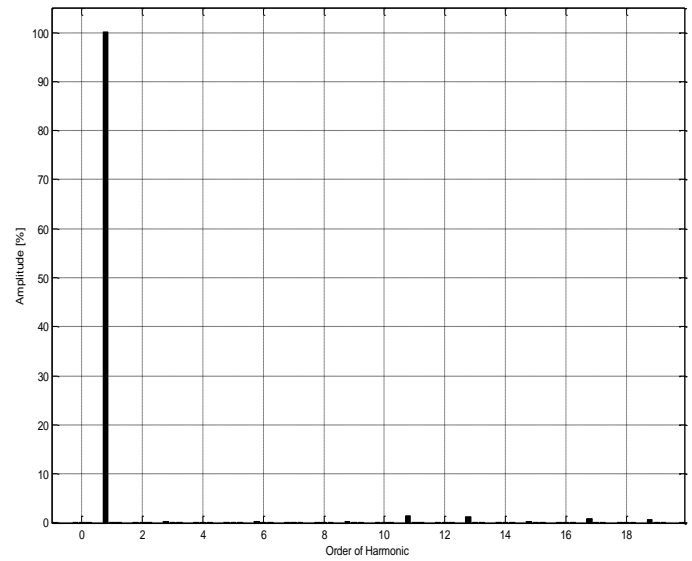

Fig. 14 Harmonic spectrum of current with HP

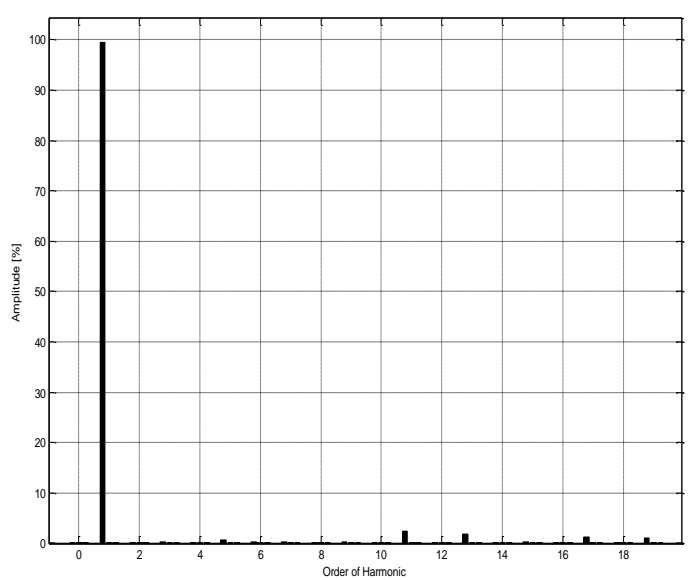

Fig. 15 Harmonic spectrum of voltage with HP

\section{Simulation Results with RC Load}
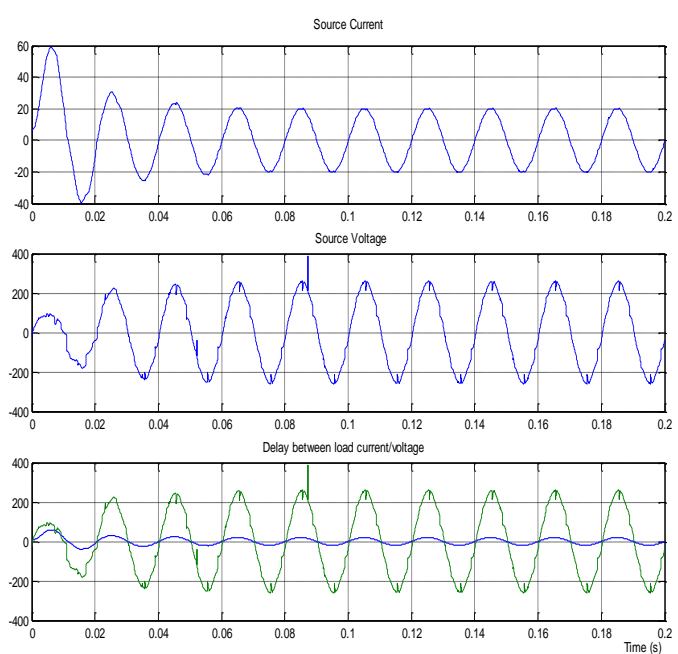

Fig. 16 Waveforms of sources (current, voltage), and their delay 


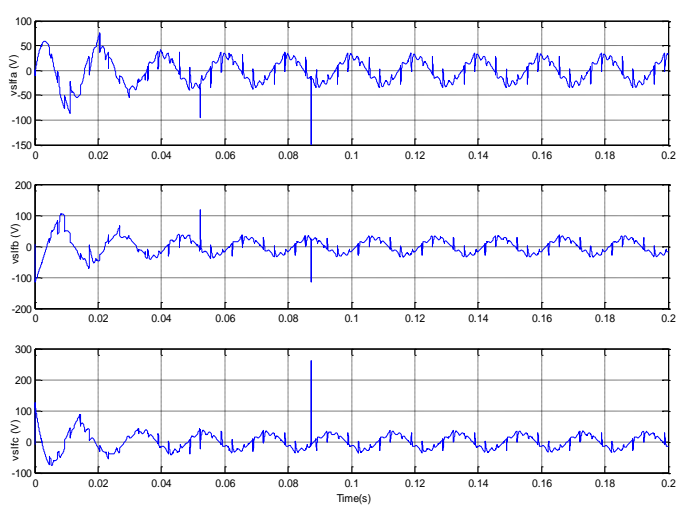

Fig. 17 Voltages references of HF for RC load

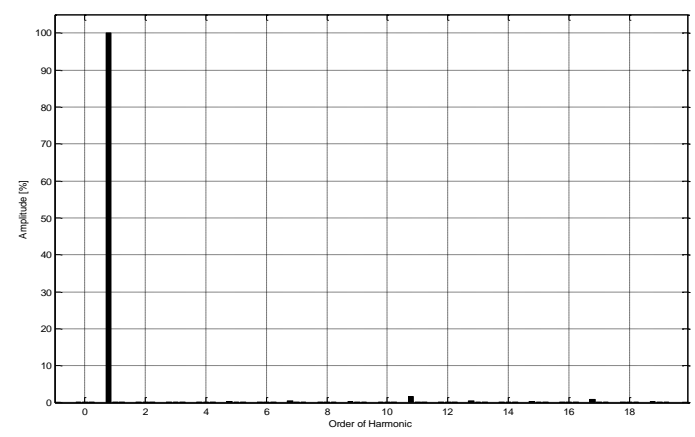

Fig. 18 Harmonic Spectrum of current

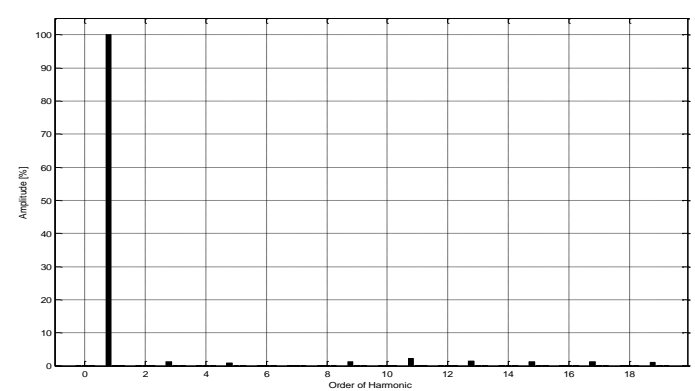

Fig19. Harmonic Spectrum of voltage

Table 2 Simulation Results of harmonics currents

\begin{tabular}{|c|c|c|c|c|}
\hline \multirow{2}{*}{$\begin{array}{c}\text { Harmonic } \\
\text { Currents }\end{array}$} & \multicolumn{2}{|c|}{ RL Load } & \multicolumn{2}{c|}{ RC Load } \\
\cline { 2 - 5 } & $\begin{array}{c}\text { Before } \\
\text { Filtering }\end{array}$ & $\begin{array}{c}\text { After } \\
\text { Filtering }\end{array}$ & $\begin{array}{c}\text { Before } \\
\text { Filtering }\end{array}$ & $\begin{array}{c}\text { After } \\
\text { Filtering }\end{array}$ \\
\hline 5 & $19,00 \%$ & $0,19 \%$ & $68,54 \%$ & $0,32 \%$ \\
\hline 7 & $12,29 \%$ & $0,03 \%$ & $44,63 \%$ & $0,46 \%$ \\
\hline 11 & $6,63 \%$ & $1,54 \%$ & $7,61 \%$ & $1,66 \%$ \\
\hline 13 & $4,93 \%$ & $1,27 \%$ & $2,07 \%$ & $0,52 \%$ \\
\hline 17 & $3,35 \%$ & $0,97 \%$ & $2,93 \%$ & $0,79 \%$ \\
\hline 19 & $2,03 \%$ & $0,59 \%$ & $1,08 \%$ & $0,31 \%$ \\
\hline THDi & $\mathbf{2 4 , 4 6 \%}$ & $\underline{\mathbf{2 , 1 9} \%}$ & $\mathbf{8 1 , 7 6 \%}$ & $\underline{\mathbf{2 , 0 3} \%}$ \\
\hline
\end{tabular}

Table 3 Simulation Results of harmonics voltages

\begin{tabular}{|c|c|c|c|c|}
\hline \multirow{2}{*}{$\begin{array}{c}\text { Harmonic } \\
\text { Voltages }\end{array}$} & \multicolumn{2}{|c|}{ RL Load } & \multicolumn{2}{c|}{ RC Load } \\
\cline { 2 - 5 } & $\begin{array}{c}\text { Before } \\
\text { Filtering }\end{array}$ & $\begin{array}{c}\text { After } \\
\text { Filtering }\end{array}$ & $\begin{array}{c}\text { Before } \\
\text { Filtering }\end{array}$ & $\begin{array}{c}\text { After } \\
\text { Filtering }\end{array}$ \\
\hline 5 & $1,14 \%$ & $0,67 \%$ & $1,35 \%$ & $0,81 \%$ \\
\hline 7 & $0,48 \%$ & $0,28 \%$ & $0,37 \%$ & $0,16 \%$ \\
\hline 11 & $4,08 \%$ & $2,42 \%$ & $4,19 \%$ & $2,33 \%$ \\
\hline 13 & $3,34 \%$ & $1,94 \%$ & $2,38 \%$ & $1,39 \%$ \\
\hline 17 & $2,12 \%$ & $1,29 \%$ & $2,44 \%$ & $1,31 \%$ \\
\hline 19 & $1,88 \%$ & $1,07 \%$ & $2,00 \%$ & $1,17 \%$ \\
\hline THDv & $\mathbf{7 , 4 9 \%}$ & $\underline{\mathbf{4 , 2 7} \%}$ & $\mathbf{8 , 1 2 \%}$ & $\underline{\mathbf{4 , 6 4} \%}$ \\
\hline
\end{tabular}

\section{CONCLUSION}

In this article, we show the advantages of the hybrid power filter which consists of a combination of shunt passive filter and series active filter to improve the power quality especially harmonic mitigation (current and voltage) in three phase system with the use of fuzzy logic controllers.

The results obtained with the use of the hybrid filter ( SAPF \& PF ) have clearly shown that mitigation are important of harmonic current of $\mathrm{THD}_{\mathrm{I}}$ from $24,46 \%$ to $2,19 \%$ ( Under the standard 5\% ); and even for harmonic voltages of $\mathrm{THD}_{\mathrm{v}}$ from 7,49 to $4,27 \%$ (Under the standard .In figure 6 shows the delay between the voltage and current source is high but the figure 14 illustrates the reduction in the time between the current and the voltage of the source; ie correcting the power factor when the hybrid filter ( SAPF \& FP) is connected .

The fuzzy logic controller has improved the performance of the equilibrium state of the series active power filter. The effectiveness of the proposed system is proved by simulation.

\section{REFERENCES}

[1] SALMERON - LITRAN: Improvement Of The Electric Power Quality Using Series Active and Shunt Passive Filters, IEEE Trans. On Power Delivery, Vol. 25, N0. 2, APRIL, 2010.

[2] SINGH, B. - AL-HADDAD, K. - CHANDRA, A.: A review of active filters for power quality improvement, IEEE Trans. Ind. Electron., Vol. 46, No. 5, pp. 960-971, Oct. 1999.

[3] CHIANG, H. K. - LIN, B. R. - KAI-TSANG, YANG - KUAN-WEI WU.: Hybrid Active Power Filter for power quality compensation, EEEE PEDS 2005, pp 950-954.

[4] LIN, B.R. - CHIANG, H.K. - HUANG, C. H.: Threephase three level active power filter with a clamped 
capacitor topology, IEE, Electric Power Applications, July 2006, pp. 513 - 522.

[5] SAAD, S. - ZELLOUMA, L.: Fuzzy logic controller for three-level shunt active filter compensating harmonics and reactive power, Elesevier, Electric Power Systems Research 79 (2009) 1337- 1341.

[6] LEE, G. M. - LEE, D. C. SEOK, J. K.: Control of series active power filters compensating for source voltage unbalance and current harmonics, IEEE Trans. Ind. Electron., vol. 51, no. 1, pp. 132139,Feb. 2004.

[7] HERRERA, R. S. - SALMERÓN, P.: Instantaneous reactive power theory : A comparative evaluation of different formulations, IEEE Trans. Power Del., vol. 22, no. 1, pp. 595-604, Jan. 2007

[8] YANG, H. - REN, S.: A practical series-shunt hybrid active power filter based on fundamental magnetic potential self-balance, IEEE Trans.Power Del., vol. 23, no. 4, pp. 2089-2096, Oct. 2008.

[9] MIKKILI, S. - PANDA, A. K.: Simulation and RTDS Hardware implementation of SHAF for Mitigation of Current Harmonics with pq and Id-Iq Control strategies using PI controller, Engineering, Technology \& Applied Science Research, Vol. 1, No. 3, pp. 54-62, 2011

[10] SURESH, M. - PANDA, A. K. - YELLASIRI, S.:
Fuzzy controller based 3phase 4wire shunt active Filter for mitigation of current harmonics with combined p-q and Id-Iq control strategies, Journal of Energy and Power Engineering, Vol. 3, No. 1, pp. 43-52, 2011

[11] GEORGE, S. - AGARWAL, V.: Optimum control of selective and total harmonic distortion in current and voltage under nonsinusoidal conditions, IEEE Trans. Power Del., vol. 23, no. 2, pp. 937-944, Aprl 2008

[12] IEEE Standard 519-1992, Recommended Practices and Requirements for Harmonic Control in Electrical Power Systems, The Institute of Electrical and Electronics Engineers, 1993.

Received February 16, 2015, accepted March 3, 2016

\section{BIOGRAPHIES}

\section{Dr. Yacine Djeghader}

Was born on 05.07.1980 in Annaba -ALGERIA- , he received the B-S degree, $\mathrm{M}-\mathrm{S}$ degree and Ph.D degree in electrical Engineering with honor from Annaba University, Algeria in 2003, 2006 and 2011 respectively.

Presently: $\mathrm{He}$ is Assistant Professor in Electrical Engineering in Souk Ahras University, Algeria;

Field of interest: Power Quality, Power System, FACTS, Power Electronic. Phone: +213665741133,

Email:djeghaderyacine@yahoo.fr

yacine.djeghader@univ-soukahras.dz 